\title{
Economic complexity to boost the selected sub-Saharan African economies
}

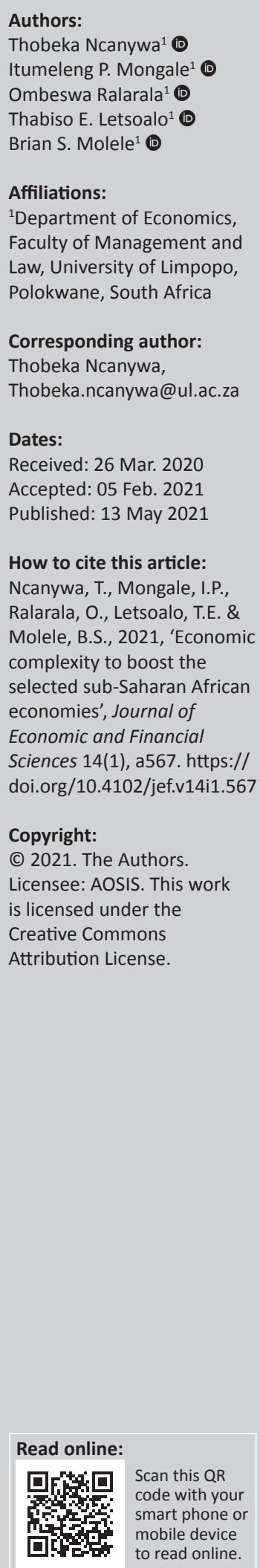

Orientation: Economic complexity is a measure of productive capabilities indirectly by looking at the mix of sophisticated products that countries export. The economic complexity index proposed a proxy for diversity and ubiquity of products in the export basket.

Research purpose: This study seeks to determine if economic complexity can influence the inequality measured by the Gini index in some selected sub-Saharan African countries.

Motivation for the study: The need for the study emanates from the notion that that economic complexity can reduce income inequality hence it is imperative to investigate this relationship in the sub-Saharan African region where most countries produce few sophisticated goods that are also labour-intensive. Inadequate literature within the African continent has also contributed to the formulation of this study.

Research approach/design and method: This study employed the autoregressive distribution lag (ARDL) model to analyze a panel data set, which includes eight sub-Saharan African countries for the period 1994-2017.

Main findings: We found that economic complexity can reduce income disparities.

Practical/managerial implications: Sub-Saharan African countries should shift their productive capabilities and resources from primary to sophisticated products in the manufacturing and services sector to increase economic complexity and reduce inequality.

Contribution/value-add: The study makes an important contribution to the debate about the relationship between economic complexity and income inequality in the sub-Saharan African context and it is envisaged that it will inform the actions of the decision-makers to drive future productivity and prosperity in the region.

Keywords: economic complexity; inequality; panel auto-regressive distributive lag; subSaharan Africa; GINI; exports.

\section{Introduction}

Sub-Saharan Africa (SSA) remained the second most disproportionate continent following Latin America and inequalities have grown over time, as shown by the Gini index (World Bank 2011). The Gini index is the measure of inequality and zero indicate complete equality whilst a value of 100 shows complete inequality. Inequalities may be reduced through several policies, such as increasing the minimum wage, progressive taxation and investing heavily on education. However, countries that attempt to reduce inequalities through these policies may experience more economic crisis. Increasing the minimum wage may induce employers to retrench workers, thus creating unemployment which could potentially increase the income gap between the rich and poor (Park 2019). In addition, taxation discourages taxpayers to work and encourage them to evade tax (Laffer 2004). The study therefore investigates economic complexity as a solution to reduce inequalities and boost selected SSA economies.

Further, a rapid economic expansion in relation to economic complexity has focused on developing a country's export sophistication (Bhorat, Steenkamp \& Rooney 2016; Hidalgo \& Hausmann 2009; Songwe 2019). It is alluded in Hidalgo and Hausmann (2009) that 'Economic complexity index (ECI) is used as a measure of productive capabilities, indirectly by looking at the mix of sophisticated products exported'. The ECI measures a country's diversity and ubiquity of products in the export basket. The consensus amongst economists is that countries with a relatively high level of economic complexity, exporting a diverse set of non-ubiquitous goods on an average, grow faster than those with a similar level of income but lower levels of economic complexity (Hausmann et al. 2013: Songwe 2019). Therefore, countries can only increase their 
score in the ECI by becoming competitive in an increasing number of complex industries (Bhorat et al. 2016; Hausmann et al. 2013).

Despite the fact that Africa is a naturally resource-rich continent, there is a need for structural transformations (McMillan \& Rodrik 2014). Monga (2018) confirmed this by suggesting that 'African economies have substantially improved their general macroeconomic conditions and performance but are still trapped in the trade of unprocessed commodities whose prices declined sharply in 2014'. In light of this, Yusuf (2017) pointed out that sustainable economic growth depends on diversification and many benefits accrue from diversified economies, not the least of which is protection from external shocks. According to Felipe et al. (2012), to be rich the economy requires to be able to produce and export commodities with unique characteristics. Therefore, this requires more of tacit knowledge rather than explicit knowledge. The index of economic complexity displays that countries differ in their export baskets. Most of the African economies produce and export natural resources such as gold, diamond, platinum, crude oil and agricultural products, which suggest that they rely heavily on the primary sector (Pérez \& Claveria 2020). This was echoed by Yellapragada (2017) who advanced that most SSA countries depend more on agricultural and natural resources than the manufacturing sector.

Despite the fact that SSA has advanced in some economic indicators like commodity prices and financing conditions in the past two decades, it has been slow on economic diversification (Yellapragada 2017). Most countries are faced with a double-edged sword of high income inequality Nallari and Griffith (2011) Yellapragada 2017). Even though there have been some debates in literature about the relationship between economic complexity and income inequality by studies such as those by Hartmann et al. (2017a), Morais, Swart and Jordaan (2018) and Lee and Vu (2013), little attention has been given to this aspect in the SSA. Therefore, this study intends to add to this emerging debate in the context of SSA and it is also envisaged that it will inform the actions of the decision-makers to drive SSA's future productivity and prosperity. Also, it seems as if there have not been any recent studies that attempted to use economic complexity as a solution to reducing income inequalities and boost SSA economies, and it is this lacuna that makes this study unique and of considerable importance.

Hartmann et al. (2017a) found that economic complexity can reduce income inequality. It is imperative to investigate if this relationship can be applicable to SSA as most countries produce few sophisticated goods that are also labourintensive. The deficiency in sophistication could result in a noticeably lower economic complexity, and that fails to boost the economy. However, it would be stimulating to observe how the selected countries in the study have performed in terms of ECI rankings and how these countries have attempted to use economic complexity to reduce income inequalities and boost their economies. The following SSA countries have been randomly chosen based on their closeness in values of ECI rankings, and also because of the availability of data: Cameroon, Cote d'Ivoire, Ghana, Kenya, Mozambique, Nigeria, South Africa and Tanzania. The chosen countries have been reported as emerging markets by Arosanyin (2017) as they show the potential for growth and can provide development opportunities. However, some studies indicated that this region is characterised by limited productive capabilities (Bhorat et al. 2016; Kanbur et al. 2017).

Hartmann et al.'s (2017a) findings of a negative correlation between ECI and inequality at the global level seem to be important because it is suggesting that if a country can build complexity, not only is it likely to grow and move to higher levels of economic development, but it can also lower its levels of income inequality. However, in SSA, we find a set of countries that have been growing in the 2000s with varying inequality levels, but for the most part we find low levels of complexity. Now, the question is does this inequalitycomplexity link also hold in the SSA context? Is it stronger or weaker than the aggregate effect?

\section{Literature review}

In order to explore the idea predicting that economic complexity can influence the economy further, the study aligns itself with the theoretical views of neo-Schumpeterian economics and evolutionary authors. Complexity ideas have been drawn from a unifying approach for evolutionary and neo-Schumpeterian streams. This pluralism is reflected in the fact that several authors such as Robert, Yoguel and Lerena (2017) who have drawn upon complexity ideas from neoSchumpeterian evolutionary theory are still debating which approach to adopt between encouraging bottom-up process and direct interventions. The concept of economic complexity can influence the economy if there is economic diversification that can provide societies with skills allowing them to produce complex products (Hartmann 2014). Economic diversification is a process of structural transformation, and in this process, there must be social networks to access information. The transformation should inspire innovation and economic diversification beyond production expansion; it is only then that economic complexity contributes to economic development, especially of human beings.

In economic complexity there are knowledge capabilities, and a country with limited knowledge capabilities can be challenged to produce complex products (Mariani et al. 2015). These findings emphasised the importance of an economy to produce complex products with the aim to address many economic ills such as inequality, unemployment and others. It has been established that countries should export a mixture of complex products and this could influence economic growth (Bustos et al. 2012). In addition Felipe, Kumar and Abdon (2014) alluded that rich countries produce and export sophisticated products.

In addition to the measure of knowledge, diversity and ubiquity seem to be crucial. Hence, an economy is regarded 
as complex if it exports different sophisticated products. Cristelli et al. (2013) posited that developed economies are extremely diversified. They export a large variety of products, whereas underdeveloped countries such as SSA countries, export products which are also exported by many other countries. This notion was also echoed by Hartmann et al. (2017a) that development of new products increase economic complexity and can be related to income inequality. González et al. (2019) stressed that sectors that promote complexity and accumulate capabilities can boost economic development. These arguments concur with Hausmann and Hidalgo's (2011) investigation which outlines the fact that underdeveloped countries have limited capabilities compared to those of developed economies. The general consensus is that when a country has limited capabilities, it tends to focus only in the production of simple products that display limited knowledge.

Countries producing more sophisticated products like Japan, Germany and the United States of America (USA) are the largest growing economies in the world that enjoy rapid economic growth. According to the ECI (2018), Japan is rated number one followed by Germany, whilst US is in the seventh place. The irony of the ECI is that according to the data from the International Monetary Forum (IMF; 2018), US has the largest economy, with a GDP amounting to 20.4 trillion, Japan is positioned in the third place with a GDP amounting to 5.1 trillion and followed by Germany in the fourth position by a GDP of 4.2 trillion, all measured in American dollars. This might be because of what products are regarded as complex. Felipe et al. (2012), list the most complex products as machinery, chemicals and metals, and the less complex products are agricultural products, raw materials, textiles and wood.

Most of the African countries are found at the bottom section of the economic complexity rankings list of 129 countries. The ECI of the chosen SSA countries are ranked in the Atlas of Economic complexity (2014) as follows: South Africa (55), Kenya (73), Tanzania (95), Cote d'Ivoire (99), Ghana (100), Mozambique (109), Cameroon (121) and Nigeria (122). Countries found in this bottom section were described by Desjardins (2017) as places where expected level of sophistication is just not there. In addition, the level of sophistication is noticeably low as the African continent fails to produce complex products and still depends heavily on the primary sector. This extracts a heavy toll on its productive capabilities to reduce inequalities and boost the economy through economic complexity. Even though it holds position 85 - way above most of the SSA countries - Venezuela' reliance on oil as an exclusively good product to pay the bills was heralded by Desjardins (2017) as an obvious example of this. Furthermore, it was shown that the most recent iteration of the index highlighted some movers and shakers over the last 10-year period. It is also noted that Botswana, Malawi, Uganda and Cameroon are some of the African countries which recently made quick improvements on their rankings; each one of them jumped over 20 spots (Desjardins 2017).

On the other hand is the fact that the SSA economies have the most unequal income distributions patterns, as compared to that of the world (Erkan \& Yildirimci 2015; Kanbur et al. 2017). Countries such as South Africa and Namibia are the world's most unequal nations in terms of income inequality (World Bank 2011). According to Cristelli et al. (2013), inequality does not depend merely on the country's growth rate, but also on the types of growth, institutions and structures of the economy. These can be illustrated by the fact that African countries are richer in mineral and agricultural resources which they produce and export mainly as raw materials, in contrast to their European counterparts. Therefore, Hausmann et al. (2013) argue that countries should not just produce products that they need but rather produce products that they can export. The phenomenon of exporting raw material is seen as a tacit lack of knowledge, which may contribute to the pattern of income inequality.

The study by Lee and $\mathrm{Vu}$ (2019) examined if economic complexity can influence income inequality using an ordinary least squares (OLS) regression analysis and generalised method of moments (GMM) estimator. The study used panel data of 96 countries from 1980 to 2014 . The results of the crosscountry OLS regression analysis indicated that economic complexity can predict income inequality. The findings from the GMM estimator indicated that there is a positive relationship between economic complexity and income inequality, and this is in contrast with the OLS estimates and Hartmann et al. (2017a)'s notion. However, it is in line with the notion that when the economy encounters structural shifts towards more sophisticated products, the level of income inequality increases. There are limited studies on the economic complexity and income inequality nexus, and even those that exist, display mixed results. The lack of consensus amongst these studies and systems open research gaps, hence this study was conducted.

\section{Methodology}

Inspired by Hartmann et al. (2017a) and Hausmann et al. (2013), this study employed the autoregressive distribution lag (ARDL) model to determine if economic complexity can influence inequality in some selected SSA countries.

\section{Data}

The study made use of a panel data set, which includes eight SSA countries that ranked highest to lowest in the region on the Atlas of Economic Complexity, for the period 1994-2017 (South Africa, Kenya, Tanzania, Cote d'Ivoire, Ghana, Mozambique, Cameroon and Nigeria). Besides the challenges with availability of data, these countries were selected to observe how countries that ranked the highest perform compared to the ones ranked lowest. Data on ECI was obtained from the Atlas of Economic Complexity by Hausmann et al. (2013) and data of other variables was obtained from the World Bank. In order to achieve the set objectives, based on some reviewed literature (Hartmann et al. 2017a; Lee \& Vu 2019; Te Velde 2003), the following model was formulated: 


$$
\begin{aligned}
L G I N I_{i t}= & \alpha+\beta_{1} E C I_{i t}+\beta_{2} L G F C F_{i t}+\beta_{3} F D I_{i t}+ \\
& \beta_{4} L G D P P C_{i t}+\varepsilon_{i t}
\end{aligned}
$$

Where, $\propto$ represents a constant parameter, LGINI is the logarithm of Gini index, ECI, LGFCF is the logarithm of gross fixed capital formation, FDI is foreign direct investment and LGDPPC is the logarithm of gross domestic product per capita, measured in purchasing power parity (US\$) as a measure of economic growth in the region. Variables that are out of range are standardised for meaningful and robust results (Brooks 2008). Hence, Gini index and gross fixed capital formation and gross domestic product per capita are transformed into logarithms to encourage a more normalised dataset and avoid the chances of producing errors when modelling variables with non-linear relationships.

It is expected that economic complexity should have a negative effect on the Gini index (Hartmann et al. 2017a). This suggests that if economic complexity increases, inequality should decline. Gross fixed capital formation is expected to have a negative relationship with the Gini index. As such, it is expected that there is an inverse relationship between inequality and fixed investment. There are mixed expectations with FDI. However, FDI is not associated with reduced inequality, but may increase inequality (Te Velde 2003). Therefore, it is expected that FDI has an inverse effect on the Gini index, whereas GDP per capita should have a negative effect on the Gini index. This suggests that as income per capita increases, inequality would decline in an economy.

\section{Empirical analysis}

The following econometric procedures will be undertaken to determine if economic complexity can influence inequality in some selected SSA countries.

\section{The panel unit roots}

The panel unit root tests are helpful in choosing the model which is suitable for the data used in the study. Before testing for cointegration (long run relationships), the study employed several approaches to test for unit root in the panel data, namely, the Fisher-Augmented Dickey-Fuller (ADF), Im, Pesaran and Shin (2003) (IPS); and Levin, Lin and Chu (2002) (LLC) tests (Maddala \& Wu 1999). Panel unit root tests are advantageous compared to individual time series unit root tests because of their standard normal asymptotic distribution. Additionally, Maddala and Wu (1999) argued that these tests allow for infinite or finite number of crosssections; the time series can be of different lengths and they allow groups to be integrated of different orders.

The IPS test was chosen because it relaxes the restrictive assumption of the LLC test (Pesaran 2007). In contrary, both the LLC and IPS tests have been criticised for requiring crosssectional independence (Baltagi, Egger \& Pfaffermayr 2007). Hence, for testing stationarity as null, Fei et al. (2011) suggested the Fisher test as the better option, and also in testing for cointegration in panel data. At the same time, Choi
(2001) pointed the importance of combining the $p$-values from a unit root test applied to each SSA country.

\section{The panel cointegration analysis}

The Kao cointegration test extends the Engle-Granger framework to test cointegration in panel data. The Kao test follows the basic approach of the Pedroni panel cointegration test, although the Kao test specifies the cross-section specific intercept and homogenous coefficients on the initial stage regressors.

The Fisher cointegration test uses the results of the individual independent tests (Fisher 1932). The panel cointegration was pioneered by Maddala and $\mathrm{Wu}$ (1999) to test for cointegration in panel data by combining the test from individual crosssections to obtain the test statistic for the entire panel.

\section{The panel autoregressive distributive lag approach}

The ARDL models are standard least squares which incorporate lags of both independent and depended variables as regressors (Pesaran \& Pesaran 1997). The ARDL approach developed by Pesaran, Shin and Smith (2001) for testing the presence of cointegration between the variables possesses more advantages over other econometric techniques. Firstly, if there are different orders of integration the ARDL method can be applied: meaning integration at order $I(0)$ and order $I(1)$, but not order I(2). Secondly, ARDL captures the long run and short run estimates simultaneously. Thirdly, the approach can be applicable on small number of observations. Fourthly, the approach can accommodate the structural breaks in time series data. Despite the advantages of ARDL over other symmetric cointegration techniques outlined above, the model is employed because variables employed in the study integrate at different orders, and the method is applicable to small sample size time series, which is the case in this study. The first step is to test for cointegration using the bounds test (Pesaran et al. 2001). Using the large sample with large number of observations addresses the bias that can be caused by the mean and error term correlation (Pesaran et al. 2001).

\section{Stability test}

The inverse root of the Autoregressive model (AR) characteristic polynomial is used to test for stability of the model. According to Agung (2011), the stability test is a reliability test that tells us the adopted model is a good one. If all the roots are inside the unit circle, the estimated model will be regarded as stable and it should be considered as acceptable in a statistical sense.

\section{Ethical considerations}

This article followed all ethical standards for a research without direct contact with human or animal subjects

\section{Results and discussion}

The first step towards achieving our goal was to determine the order of integration of the variables through unit root 
testing. It was found that the three tests (LLC, IPC, FisherADF) show a mixture of levels (I[0]) and first order (I[1]) integration variables in the Gini index models of the selected SSA countries (see Appendix 1, Table 1-A1). We note that the Gini coefficient as our dependent variable is integrated of order one and our main independent variable, ECI is integrated at level. These outcomes give us a go-ahead to run the panel ARDL model as highlighted by Pesaran et al.'s (2001) assumption that, when applying the panel ARDL approach, the dependent variable should be integrated with the first order. It is also notable that none of the variables employed in the study are integrated with the second order. This is because according to Pesaran, Shin and Smith (1999) the panel ARDL model is more appropriate when there is a presence of unit root or a mixed order of integration of not more than I(1). Panel ARDL approach is advantageous in the sense that it emphasises and allows for the possibilities of estimating different variables with different order of stationarity (Rafindadi \& Yosuf 2013).

After determining the order of the integration, the next step was to establish the presence of cointegration in the system. The Kao panel cointegration test was employed and the results with the deterministic trend specification of individual intercepts are presented in Appendix 1, Table 2-A1. The result of the Kao residual panel cointegration rejects the null hypothesis of no cointegration at $5 \%$ level of significant for the Gini-coefficient model. These results concur with the findings of Li and Luo (2010). Furthermore, the Johansen Fisher panel cointegration tests were conducted and the results are presented in Appendix 1, Tables 3-A1, 4-A1 and 5-A1 are fairly conclusive. The Fisher's test results support the presence of cointegration amongst the variables, and this concurs with the Kao panel cointegration results in Appendix 1, Table 2-A1. Therefore, we reject the null hypothesis of no cointegration amongst the variables. According to Dickey et al. (1994), if the results show the existence of more than one cointegrating vector, the implication is that the estimated model is stationary in more than one direction. Furthermore, Lee and Lee (2010) emphasised that such analysis is robust and sensitive, implying that the variables co-move in the long run.

The next step was to find the long run and short run estimates in the system, and the results are presented in Tables 1 and 2, respectively. Table 1 provides the ARDL long-run relationship estimates of the model.

In order to capture the impact and also the relationship between Gini-coefficient and its regressors, the coefficients $\beta 1$ to $\beta 4$ from Equation 1 are replaced by the corresponding

TABLE 1: Panel autoregressive distribution lag long-run estimates.

\begin{tabular}{lcccc}
\hline Variable name & Coefficients & Standard error & $\boldsymbol{t}$-statistic & Probability \\
\hline ECI & -0.006338 & 0.003427 & -1.849480 & 0.0671 \\
LGFCF & 0.184012 & 0.011395 & 16.14835 & 0.0000 \\
FDI & 0.006588 & 0.000773 & 8.527436 & 0.0000 \\
LGDPPC & -0.017070 & 0.010962 & -1.557234 & 0.1224 \\
\hline
\end{tabular}

$\mathrm{ECI}$, economic complexity index; FDI, foreign direct investment; LGDPPC, logarithm of gross domestic product per capita; LGFCF, logarithm of gross fixed capital formation. computed coefficients values from Table 1 to generate the model's long equation represented by equation 10 as follows:

$L_{G I N I}{ }_{i t}=0.046-0.006 E C I+0.184 L G F C F+$

$0.007 F D I-0.017 L G D P P C$

[Eqn 2]

The long run equation indicates that if ECI increase by a percentage, GINI coefficient (LGINI) will decrease by 0.006 , and has a significant negative influence on dependent variable. These findings concur with Hartmann et al. (2017a) that economic complexity is a negative and significant predictor of income inequality. We can therefore safely say that this notion also holds in SSA countries and that economic complexity can reduce income inequality. The findings further reveal that a country's range of inequality is limited by its productive structure and capabilities. The notion that when an economy experiences structural shifts towards the production of complex products, the level of inequality increases, does not hold in SSA countries. However, this notion gives an idea of what happens if these countries experience rapid shifts towards more sophisticated products. This is because the production of these products may only benefit the highly skilled and the knowledgeable, as they would be the only ones with the necessary capabilities to produce these products. In contrast, gross domestic product (LGDPPC) has an insignificant negative impact on income inequality.

Finally, the remaining macroeconomic variables demonstrate a significant positive influence on the dependent variable because the implication is that if gross fixed capital formation (LGFCF) and FDI go up by 1\%, GINI coefficient will increase by 0.184 and 0.007 , respectively. With regards FDI, the results concur with the findings of Kaulihowa and Adjasi (2018) who discovered that FDI increases equality of distribution of income. However, these results contradicts with the literature that FDI and gross fixed capital formation are expected to have an inverse influence on inequality. Foreign direct investment results further concur with the likes of Te Velde (2003) that FDI is not associated with reduced inequality, but may increase inequality.

After cointegration, the next step was the estimation of the short run analysis. The purpose was to use the error correction model to determine both the speed of adjustment and also the short run estimates for each variable on the Gini coefficient. Speed of adjustment is reflected by how much percentage equilibrium will be restored in the next period and the results are presented in Table 2 .

TABLE 2: Autoregressive distribution lag short run analysis results.

\begin{tabular}{lcccc}
\hline Variable names & Coefficients & Standard error & $\boldsymbol{t}$-statistic & Probability \\
\hline ECT(-1) & -0.303740 & 0.155029 & -1.959251 & 0.0527 \\
D(ECI) & -0.007905 & 0.015066 & -0.524672 & 0.6009 \\
D(ECI(-1)) & 0.007864 & 0.006126 & 1.283714 & 0.2020 \\
D(LGFCF) & -0.070737 & 0.024906 & -2.840187 & 0.0054 \\
D(LGFCF(-1)) & 0.015471 & 0.020946 & 0.738591 & 0.4618 \\
D(FDI) & -0.001165 & 0.001006 & -1.158768 & 0.2491 \\
\hline
\end{tabular}

$\mathrm{ECl}$, economic complexity index; FDI, foreign direct investment; LGFCF, logarithm of gross fixed capital formation. 


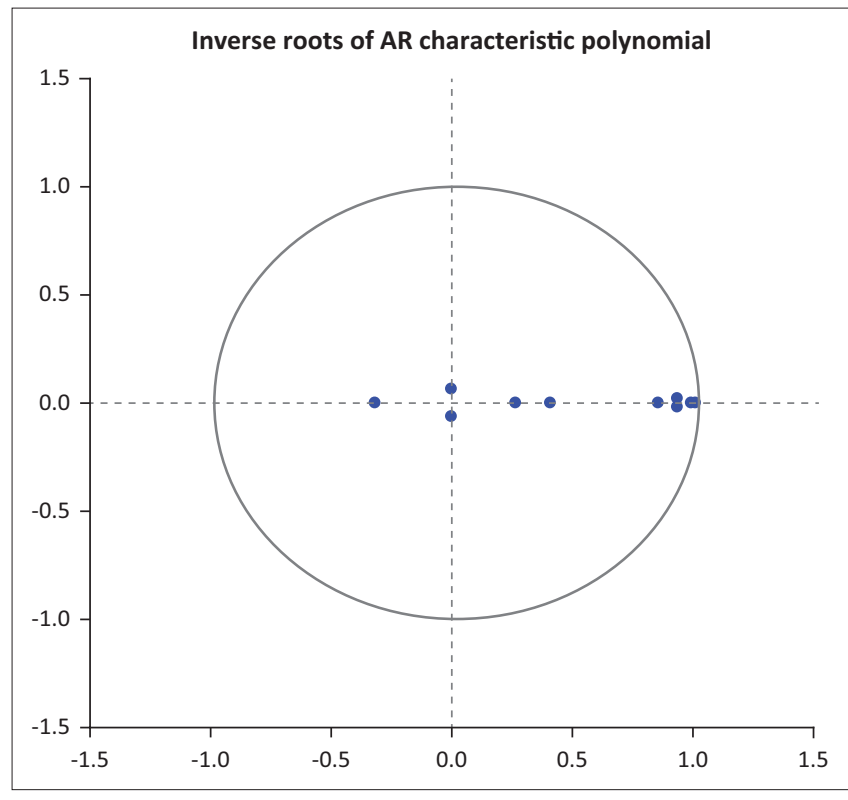

FIGURE 1: Stability reliability test.

Based on Table 2 the coefficient of the of error correction term (ECT) of -0.30 is negative and significant. The negative sign demonstrates that a dependent variable will return to equilibrium after a change in other variables, whereas the value determines the speed at which the return will take place. Therefore, about $30.37 \%$ of the disequilibrium in the Gini-coefficient model will be restored in the next coming year if changes are made to ECI and the other macroeconomic variables as per their respective influences. The implication is that any change in the short run towards long run is corrected by around $30 \%$ per year in the SSA countries. These estimates are proven to be significant at $10 \%$ level.

In order to investigate whether the long run relationships established earlier are stable over the proposed period of study, the inverse root of AR characteristic polynomial was employed and the results are presented in Figure 1.

Figure 1 depicts the inverse AR characteristics polynomial graph that is the stability reliability test. This test confirms the stability of the model based on the fact that all the dots are found inside the unit circle. Therefore, the estimated model of economic complexity and inequality is stable and reliable for statistical estimation.

\section{Conclusion}

The study intended to determine if economic complexity can influence inequality in some selected SSA countries. This was achieved by determining whether economic complexity is a significant and negative predictor of income inequality in the region. The panel autoregressive distributive lag (ARDL) model was found to be a suitable approach for the analysis after the results of the three tests showed a mixture of orders of integration (I[0] and $I[1])$ and the fact that there was no second order $(I[2])$ variable in the system. Both the Kao and the Fisher's tests confirmed the presence of cointegration amongst the variables and the panel ARDL long run and short run estimates were performed.

The long run analysis indicated that even though it was found to be statistically significant at the 10\% level, ECI together with GDP per capita have the expected negative influence on the Gini coefficient. These findings are in cohesion with the findings of Cristelli et al. (2016) and as such the views of Yellapragada (2017) that the SSA countries should have a common element of shifting resources from low-productivity activities to high productivity activities is further magnified. This practice might improve ECI for the stated countries, and realise an improved developmental state with an enhanced income inequality.

Sub-Sahara African countries should also expand their productive capabilities from primary sector to manufacturing and services sector, to produce and export more complex and sophisticated products. This allows for a far better ECI and thus reduces inequality. Further, negotiating an increased minimum wage with employers by government and trade unions may help bridge the income gap between rich and poor. These policies must be implemented by not only the selected SSA countries, but also the members of the AfCFTA which envisaged stimulated export sophistication across the continent.

Furthermore, gross fixed capital formation and FDI have a positive effect on the Gini-coefficient and they are significant at $1 \%$ level. With regards to FDI, these results concur with the findings of Kaulihowa and Adjasi (2018) who discovered that FDI increases equality of distribution of income. Thus, FDI should be encouraged in the respective SSA and other African Sub-Saharan countries as a tool to governments to also gain export markets. Firms can gain access to export markets by using global networks of multinationals through FDI as one dynamic benefits of FDI (Te Velde 2003). Therefore, an improved economic complexity, as alluded above, will also be incentivised through increased global export markets. It would be interesting for future research to investigate product space capabilities in SSA, calculating the proximity of countries.

\section{Acknowledgements Competing interests}

The authors have declared that no competing interests exist.

\section{Authors' contributions}

All authors contributed equally to this work.

\section{Funding information}

This research received no specific grant from any funding agency in the public, commercial or not-for-profit sectors.

\section{Data availability}

Data sharing is not applicable to this article as no new data were created but obtained from reliable sources mentioned in the article. 


\section{Disclaimer}

The views and opinions expressed in this article are those of the authors and do not necessarily reflect the official policy or position of any affiliated agency of authors.

\section{References}

Agung, I.G., 2011, Time series data analysis using EViews, John Wiley \& Sons, New York, NY.

Arosanyin, K., 2017, 'Navigating Business Complexities in Sub-Saharan Africa', Global Trade Magazine, viewed 27 March 2019, from http://www.globaltrademag.com/ global-trade-daily/navigating-complexities-business-sub-saharan-africa/.

Baltagi, B.H., Egger, P. \& Pfaffermayr, M., 2007, 'Estimating models of complex FDI: Are there third-country effects?', Journal of Econometrics 140(1), 260-281. https:// doi.org/10.1016/j.jeconom.2006.09.009

Bhorat, H., Steenkamp, F. \& Rooney, C., 2016, Africa's manufacturing Malaise, viewed 27 March 2019, from https://scholar.google.com/scholar?hl=en\&as sdt=0\%2C5 $\& q=B$ horat $\% 2 \mathrm{C}+\mathrm{H} . \% 2 \mathrm{C}+\mathrm{Steenkamp} \% 2 \mathrm{C}+\mathrm{F} .+\% 26+$ Rooney $\% 2 \mathrm{C}+\mathrm{C} . \% 2 \mathrm{C}+2016 \% 2$ $\& \mathrm{q}=\mathrm{Bhorat} \% 2 \mathrm{C}+\mathrm{H} . \% 2 \mathrm{C}+$ Steenkamp $\% 2 \mathrm{C}+\mathrm{F} .+\% 26+$ Rooney $\% 2 \mathrm{C}+\mathrm{C} . \% 2 \mathrm{C}+2016 \% 2$
C+Africa $\% \mathrm{E} 2 \% 80 \% 99 \mathrm{~s}+$ manufacturing+Malaise $\% 2 \mathrm{C}+\mathrm{viewed}+27+$ March $+2019 . \&$ btnG.

Brooks, C., 2008, Introductory econometrics of finance, 2nd edn., Cambridge University Press, Cambridge.

Bustos, S., Gomez, C., Hausmann, R. \& Hidalgo, C.A., 2012, 'The dynamics of nestedness predicts the evolution of industrial ecosystems', PLoS One 7(11), e49393. https://doi.org/10.1371/journal.pone.0049393

Choi, I., 2001, 'Unit root tests for panel data', Journal of International Money and Finance 20(2), 249-272. https://doi.org/10.1016/S0261-5606(00)00048-6

Cristelli, M., Gabrielli, A., Tacchella, A., Caldarelli, G. \& Pietronero, L., 2013, 'Measuring the intangibles: A metrics for the economic complexity of countries and products', PLoS One 8(8), e70726. https://doi.org/10.1371/journal.pone.0070726

Dickey, D.A., Jansen, D.W. \& Thornton, D.L., 1994, 'A primer on cointegration with an application to money and income', in Cointegration, Palgrave Macmillan, London.

Desjardins, J., 2017, 'Which countries have the most economic complexity?', Visual Capitalist, viewed 19 June 2019, from https://www.visualcapitalist.com/ countries-economic-complexity/.

Erkan, B. \& Yildirimci, E., 2015, 'Economic complexity and export competitiveness: The case of Turkey', Procedia-Social and Behavioral Sciences 195(1), 524-533. https:// doi.org/10.1016/j.sbspro.2015.06.262

Fei, L., Dong, S., Xue, L., Liang, Q. \& Yang, W., 2011, 'Energy consumption-economic growth relationship and carbon dioxide emissions in China', Energy Policy 39(2), 568-574. https://doi.org/10.1016/j.enpol.2010.10.025

Felipe, J., Kumar, U. \& Abdon, A., 2014, 'How rich countries became rich and why poor countries remain poor: It's the economic structure... duh!', Japan and the World Economy 29(1), 46-58. https://doi.org/10.1016/j.japwor.2013.11.004

Felipe, J., Kumar, U., Abdon, A. \& Bacate, M., 2012, 'Product complexity and economic development', Structural Change and Economic Dynamics 23(1), 36-68. https:// doi.org/10.1016/j.strueco.2011.08.003

González, A., Ortigoza, E., Llamosas, C., Blanco, G. \& Amarilla, R., 2019, 'Multi-criteria analysis of economic complexity transition in emerging economies: The case of Paraguay', Socio-Economic Planning Sciences 68(1), 100617. https://doi. org/10.1016/j.seps.2018.02.004

Hartmann, D., 2014, Economic complexity and human development: How economic diversification and social networks affect human agency and welfare, Taylor \& Francis, New York.

Hartmann, D., Guevara, M.R., Jara-Figueroa, C., Aristarán, M. \& Hidalgo, C.A., 2017a, 'Linking economic complexity, institutions, and income inequality', World Development 93(1), 75-93. https://doi.org/10.1016/j.worlddev.2016.12.020

Hausmann, R. \& Hidalgo, C.A., 2011, 'The network structure of economic output', Journal of Economic Growth 16(4), 309-342. https://doi.org/10.1007/s10887011-9071-4

Hausmann, R., Hidalgo, C.A., Bustos, S., Coscia, M. \& Simoes, A., 2013, The atlas of economic complexity: Mapping paths to prosperity, MIT Press, Cambridge, MA.

Hidalgo, C.A. \& Hausmann, R., 2009, 'The building blocks of economic complexity', Proceedings of the National Academy of Sciences 106(26), 10570-10575. https:// doi.org/10.1073/pnas.0900943106

Im, K.S., Pesaran, M.H. \& Shin, Y., 2003, 'Testing for unit roots in heterogeneous panels', Journal of econometrics 115(1), 53-74.
Kanbur, R., Steenkamp, F., Rooney, C. \& Bhorat, H., 2017, Sub-Saharan Africa's manufacturing sector: Building Complexity (No. 12073), CEPR Discussion Paper.

Kaulihowa, T. \& Adjasi, C., 2018, 'FDI and income inequality in Africa', Oxford Development Studies 46(2), 250-265. https://doi.org/10.1080/13600818.2017. 1381233

Li, S. \& Luo, C., 2010, 'Re-estimating the income gap between urban and rural households in China', in M. Whyte (ed.), One country, two societies: Rural-urban inequality in contemporary China, Harvard University Press, Cambridge, MA.

Laffer, A.B., 2004, 'The Laffer curve: Past, present, and future', Backgrounder 1765(1), $1-6$.

Lee, C. \& Lee, J., 2010, 'A panel data analysis of the demand for total energy and electricity in OECD countries', Energy Journal 31(1), 1-23.

Lee, K.K. \& Vu, T.V., 2013, 'Economic complexity, human capital and income inequality: A cross-country analysis', The Japanese Economic Review 1-24.

Maddala, G.S. \& Wu, S., 1999, 'A comparative study of unit root tests with panel data and a new simple test', Oxford Bulletin of Economics and Statistics 61(S1), 631-652. https://doi.org/10.1111/1468-0084.0610s1631

Mariani, M.S., Vidmer, A., Medo, M. \& Zhang, Y.C., 2015, 'Measuring economic complexity of countries and products: which metric to use?', The European Physical Journal B 88(11), 1-9.

McMillan, M.S. \& Rodrik, D., 2011, Globalization, structural change and productivity growth, National Bureau of Economic Research, Cambridge.

Monga, C., 2018, 'Foresight Africa viewpoint - The global dividends of Africa's industrialization', Africa in Focus, viewed 20 June 2019, from https://www. brookings.edu/blog/africa-in-focus/2018/01/24/foresight-africa-viewpoint-theglobal-dividends-of-africas-industrialization/.

Morais, M.B., Swart, J. \& Jordaan, J.A., 2018, Economic complexity and inequality: Does productive structure affect regional wage differentials in Brazil? Working Paper series (vol. 18, No. 11), U.S.E Research Institute, Utrecht.

Nallari, R. \& Griffith, B., 2011, 'Understanding Growth and Poverty: Theory, Policy, and Empirics', The International Bank for Reconstruction and Development/The World Bank, The World Bank, Washington DC. https://doi.org/10.1596/978-0-82136953-1

Park, J.D., 2019, Re-inventing Africa's development: Linking Africa to the Korean development model, Springer Nature, London.

Pérez, C. \& Claveria, O., 2020, 'Natural resources and human development: Evidence from mineral-dependent African countries using exploratory graphical analysis', Resources Policy 65(1), 101535. https://doi.org/10.1016/j.resourpol.2019.101535

Pesaran, M.H., 2007, 'A simple panel unit root test in the presence of cross-section dependence', Journal of Applied Econometrics 22(2), 265-312. https://doi. org/10.1002/jae.951

Pesaran, M.H. \& Pesaran, B., 1997, Working with Microfit 4: Microfit 4 user manual, Oxford university press, Oxford.

Pesaran, M.H., Shin, Y. \& Smith, R.P., 1999, 'Pooled mean group estimation of dynamic heterogeneous panels', Journal of the American statistical Association 94(446), 621-634. https://doi.org/10.1002/jae.616

Pesaran, M.H., Shin, Y. \& Smith, R.J., 2001, 'Bounds testing approaches to the analysis of level relationships', Journal of Applied Econometrics 16(3), 289-326. https:// doi.org/10.1002/jae.616

Rafindadi, A.A. \& Yosuf, Z., 2013, 'An application of panel ARDL in analysing the dynamics of financial development and economic growth in 38 sub-Saharan African continents', in Proceeding-Kuala Lumpur International Business, Economics and Law Conference, Kuala Hotel Putra, Kuala Lumpur, Malaysia, December 2 2013, pp. 118-135.

Robert, V., Yoguel, G. \& Lerena, O., 2017, 'The ontology of complexity and the neoSchumpeterian evolutionary theory of economic change', Journal of Evolutionary Economics 27(4), 761-793. https://doi.org/10.1007/s00191-017-0512-x

Songwe, V., 2019, 'Intra-African trade: A path to economic diversification and inclusion', in B.S. Coulibaly (eds.), Foresight Africa: Top priorities for the continent in 2019, pp. 97-116, United Nation Economic Commission for Africa, Addis Ababa, Ethiopia.

Te Velde, D.W., 2003, Foreign direct investment and income inequality in Latin America: Experiences and policy implications, Documento de Trabajo, London.

Yellapragada, K.K., 2017, Economic diversification in sub-Saharan Africa, International Monetary Fund, Washington, DC.

Yusuf, K., 2017, Why African economies need to diversify, Association of Chartered Certified Accountants, ACCA Global, viewed 19 June 2018, from https://www. accaglobal.com/an/en/member/member/accounting-Business/2017/11/ accaglobal.com/an/en/memb
insights/africa-diversify.html.

World Bank, 2011, World development indicators CD-ROM 2011, Washington, DC. 


\section{Appendix 1}

\section{Unit root and cointegration tests}

TABLE 1-A1: Summary of panel unit root test.

\begin{tabular}{|c|c|c|c|c|}
\hline \multicolumn{2}{|c|}{ Variables Tests } & \multirow{2}{*}{$\begin{array}{l}\text { Tests equations } \\
\text { Individual and intercept }\end{array}$} & \multirow{2}{*}{$\begin{array}{c}p \text {-value } \\
\text { (level) }\end{array}$} & \multirow{2}{*}{$\begin{array}{c}p \text {-value (1st } \\
\text { difference) }\end{array}$} \\
\hline LGINI & LLC & & & \\
\hline & & Individual, intercept and trend & 0.9649 & 0.0000 \\
\hline & & None & 0.9167 & 0.0000 \\
\hline & IPS & Individual and intercept & 0.6349 & 0.0000 \\
\hline & & Individual, intercept and trend & 0.9478 & 0.0001 \\
\hline & Fisher-ADF & Individual and intercept & 0.8805 & 0.0000 \\
\hline & & Individual, intercept and trend & 0.9833 & 0.0008 \\
\hline & & None & 0.9966 & 0.0000 \\
\hline \multirow[t]{7}{*}{$\mathrm{ECl}$} & LLC & Individual and intercept & 0.0026 & - \\
\hline & & Individual, intercept and trend & 0.0171 & - \\
\hline & & None & 0.0397 & - \\
\hline & IPS & Individual and intercept & 0.0010 & - \\
\hline & & Individual, intercept and trend & 0.0035 & - \\
\hline & Fisher-ADF & Individual and intercept & 0.0012 & - \\
\hline & & Individual, intercept and trend & 0.0082 & - \\
\hline \multirow[t]{8}{*}{ LGFCF } & LLC & Individual and intercept & 0.3095 & 0.0000 \\
\hline & & Individual, intercept and trend & 0.2108 & 0.0000 \\
\hline & & None & 0.1770 & 0.0000 \\
\hline & IPS & Individual and intercept & 0.3237 & 0.0000 \\
\hline & & Individual, intercept and trend & 0.0890 & 0.0000 \\
\hline & Fisher-ADF & Individual and intercept & 0.4277 & 0.0000 \\
\hline & & Individual, intercept and trend & 0.1236 & 0.0000 \\
\hline & & None & 0.6858 & 0.0000 \\
\hline \multirow[t]{8}{*}{ LGDPPC } & LLC & Individual and intercept & 0.5776 & 0.0004 \\
\hline & & Individual, intercept and trend & 0.6216 & 0.0003 \\
\hline & & None & 1.0000 & 0.0022 \\
\hline & IPS & Individual and intercept & 0.9985 & 0.0014 \\
\hline & & Individual, intercept and trend & 0.6750 & 0.0200 \\
\hline & Fisher-ADF & Individual and intercept & 0.5776 & 0.0035 \\
\hline & & Individual, intercept and trend & 0.6216 & 0.0223 \\
\hline & & None & 1.0000 & 0.0493 \\
\hline \multirow[t]{8}{*}{ FDI } & LLC & Individual and intercept & 0.1305 & 0.0000 \\
\hline & & Individual, intercept and trend & 0.7326 & 0.0000 \\
\hline & & None & 0.0077 & - \\
\hline & IPC & Individual and intercept & 0.0054 & - \\
\hline & & Individual, intercept and trend & 0.0519 & - \\
\hline & Fisher-ADF & Individual and intercept & 0.0135 & - \\
\hline & & Individual, intercept and trend & 0.0912 & - \\
\hline & & None & 0.1152 & 0.0000 \\
\hline
\end{tabular}

ADF, Augmented Dickey-Fuller; ECl, economic complexity index; FDI, foreign direct investment; IPC, Im, Pesaran and Shin tests; LGDPPC, logarithm of gross domestic produc per capita; LGFCF, logarithm of gross fixed capital formation; LGINI, logarithm of Gini index LLC, Levin, Lin and Chu tests.

TABLE 2-A1: Kao panel cointegration test results.

\begin{tabular}{lcc}
\hline Variable & $\boldsymbol{t}$-statistics & $p$ \\
\hline ADF & -1.819179 & 0.0344 \\
Residual variance & 0.000220 & - \\
HAC variance & 0.000200 & - \\
\hline
\end{tabular}

ADF, Augmented Dickey-Fuller; HAC, Heteroskedasticity- and autocorrelation-consistent.
TABLE 3-A1: Johansen Fisher panel cointegration with linear deterministic trend test. Hypothesised number Fisher stat. Probability Fisher stat. Probability

\begin{tabular}{|c|c|c|c|c|}
\hline of CE(s) & (trace test) & 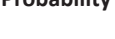 & (max-eigen test) & - \\
\hline None & $197.1 * * *$ & 0.0000 & $149.1 * * *$ & 0.0000 \\
\hline At most 1 & $75.57 * * *$ & 0.0000 & $53.33 * * *$ & 0.0000 \\
\hline At most 2 & $36.61 * *$ & 0.0024 & $27.14 * *$ & 0.0400 \\
\hline At most 3 & 22.24 & 0.1356 & 17.86 & 0.3319 \\
\hline At most 4 & $26.81 * *$ & 0.0436 & $26.81 * *$ & 0.0436 \\
\hline
\end{tabular}

Note: $*, * *$, and $* * *$ indicate that the $p$-values are significant at $10 \%, 5 \%$ and $1 \%$ level of significance, respectively. The Fisher's test applies regardless of the dependent variable.

$\mathrm{CE}$, cointegrating equation

TABLE 4-A1: Johansen Fisher panel cointegration test with no deterministic trend test.

\begin{tabular}{lcccc}
\hline $\begin{array}{l}\text { Hypothesized } \\
\text { number of CE(s) }\end{array}$ & $\begin{array}{c}\text { Fisher stat. } \\
\text { (trace test) }\end{array}$ & Probability & $\begin{array}{c}\text { Fisher stat. } \\
\text { (max-eigen test) }\end{array}$ & Probability \\
\hline None & $165.6 * * *$ & 0.0000 & $125.7 * * *$ & 0.0000 \\
At most 1 & $63.34 * * *$ & 0.0000 & $43.04 * * *$ & 0.0003 \\
At most 2 & $34.33^{* * *}$ & 0.0049 & $24.24 *$ & 0.0844 \\
At most 3 & $24.18^{*}$ & 0.0856 & $23.75 *$ & 0.0952 \\
At most 4 & 13.43 & 0.6412 & 13.43 & 0.6412 \\
\hline
\end{tabular}

Note: $*, * *$, and $* * *$ indicate that the $p$-values are significant at $10 \%, 5 \%$ and $1 \%$ level of significance, respectively. The Fisher's test applies regardless of the dependent variable.

$\mathrm{CE}$, cointegrating equation.

TABLE 5-A1: Johansen Fisher panel cointegration test with Quadratic deterministic trend.

\begin{tabular}{lcccc}
\hline $\begin{array}{l}\text { Hypothesised } \\
\text { number of CE(s) }\end{array}$ & $\begin{array}{c}\text { Fisher stat. } \\
\text { (trace test) }\end{array}$ & Probability & $\begin{array}{c}\text { Fisher stat. } \\
\text { (max-eigen test) }\end{array}$ & Probability \\
\hline None & $214.0 * * *$ & 0.0000 & $143.2 * * *$ & 0.0000 \\
At most 1 & $91.31 * * *$ & 0.0000 & $59.85 * * *$ & 0.0000 \\
At most 2 & $46.47^{* * *}$ & 0.0001 & $28.11^{* *}$ & 0.0307 \\
At most 3 & $30.32 * *$ & 0.0164 & 19.85 & 0.2270 \\
At most 4 & $39.84 * * *$ & 0.0008 & $39.84 * * *$ & 0.0008 \\
\hline
\end{tabular}

Note: $*, * *$, and $* * *$ indicate that the $p$-values are significant at $10 \%, 5 \%$ and $1 \%$ level of significance, respectively. The Fisher's test applies regardless of the dependent variable.

$\mathrm{CE}$, cointegrating equation. 